\title{
SPORT STUDENT FOREIGN LANGUAGE LEARNING AND USE HABITS
}

\author{
Ieva Rudzinska \\ Monta Jakovl̦eva \\ Latvian Academy of Sport Education, Latvia
}

\begin{abstract}
The aim of the research is to analyze sport student foreign language (English) learning and use habits in longitudinal scale (past, present and future prospective). Subjects are 35 Latvian Academy of Sport Education Full and Part time students. Methods: mixedqualitative and quantitative. Interviews with three students led to designing a questionnaire, consisting of 12 statements. Results were analyzed with SPSS 17.0. Results show that students learn and use English both in sportive and non-sportive environment, active sporting life promotes foreign language learning. Most of them self-assess their English use skills as moderate. At present they use English more than in past, in future more than in present, and in future much more than in past $(r=0.5, p<0.001)$.
\end{abstract}

Keywords: Sport students, foreign language learning, sport English.

\section{Introduction}

Research on the development of verbal skills in most cases reveals female superiority to males. Results of the Progress in International Reading Literacy Study (PIRLS) by the International Association for the Evaluation of Educational Achievement 2001 show that the reading achievement, attitude to reading, as well as self assessment of reading among $4^{\text {th }}$ grade girls is significantly higher than that of $4^{\text {th }}$ grade boys (Johansone, 2003). Evidence shows that 15 year old girls in all the countries participating in the Programme for International Student Assessment (PISA) by the Organization for Economic Co-operation and Development (OECD) 2000 surpass their male peers in reading literacy (Geske, \& Ozola, 2007).

However, a number of researchers have questioned female verbal superiority (Cameron, 2007); others have provided evidence that the difference between men and women is shrinking (Wolf \& Zwick, 2002).

Several investigations about sport students reveal that male verbal skills are not lower than those of females, moreover, in some cases, they are even higher than those of females (Omrčen \& Bosnar, 2010; Rudzinska, 2011). Causes for the last finding could be at least three-fold: 1) physiological (sport student increased level of testosterone), 2) psychological (increased self-esteem) and 3) social (communicating in training, camp and competition international environment). Willingness to communication can develop habits of regular communication, including one in foreign languages.

In the light of recent investigations in neuroscience female brain is found to differ essentially from male brain. In the brain center for language and hearing women have 11 percent more neurons than men. males, in their turn, have higher levels of hormone testosterone, and male brain space, devoted to sexual 
drive, two and a half times exceeds that of females (Brizendine, 2006:5-6). Increased levels of testosterone are found to decrease willingness to socialize. However, there are two exceptions: engagement in sports activities and in sexual intercourse. These situations increase willingness to communicate. Increased willingness to communicate might lead to better development of verbal skills.

Sports person development of foreign language skills might be affected by psychological causes too. People performance is influenced by their self-esteem. People who actively participate in physical activities develop a better perception of themselves (Sonstroem, 1997). The increased level of self-perception could positively affect also the development of verbal skills.

Omrčen (Omrčen \& Bosnar, 2010) suggests that participation in sports more alters female life than male life. In order to be successful in sports females might have to suppress their natural willingness to actively engage in social life because they simply lack time for them. However, apart from usual young people settings for socializing, sports persons have a lot of opportunities to socialize in trainings, training camps and competitions, frequently in an international environment. These situations might be crucial in the development of sports person foreign language skills.

Research questions were connected with sportsperson foreign language learning in longitudinal scale (past, present and future prospective). We aimed to find out how sportsmen develop their foreign language skills, does it occur more in formal (school, university) or informal occasions; Are sport students satisfied with the development of their foreign language skills, what is the range of the use of their foreign language skills; Does participation in sport relating activities promote (or maybe impede) the development of foreign language skills?

The sample consisted of 35 full and part time Year 1 and Year 2 students, both genders.

The research combined qualitative and quantitative methods. In the first classes of academic year 2012/2013 first and send year full and part time students were asked to reflect on the following issues: How did you learn English? Who and what helped you learn English? Qualitative analysis of student answers allowed identifying key words, characterizing ways of learning English. Afterwards was designed a questionnaire, consisting of 12 questions with responses in 4-point Likert scale.

\section{Qualitative analysis}

Qualitative analysis revealed different ways how students in formal and informal learned and learn foreign languages, their language use habits in past and present. Some characteristic excerpts from student answers are given below: Competitions are really good occasions to communicate with other sports people. When I was in Germany, we lived with girls from Poland when we had free time, we used to draw some rowing equipment, and with the team tried to 
guess what it was, there I picked up such words as single scull, double sculls, a.o.

\section{G.G., female, Year 2 full-time student}

I was in Sweden as an exchange student. When I had my workout in the gym, the coach who worked there, told me (in English) about some techniques and interesting exercises for arm and stomach muscles, afterwards he explained me the theory.

A. S., Year 2, male, part-time student

I started travelling around with my hockey team from the age of 10, and I have been studying English for two years then. We were on our way to the USA when a woman from back seat of the plane tapped me on the shoulder and asked where from where we were. I had never used English outside the classroom, but then I pulled myself together and replied - We are from Latvia... my English was far from good at that age, but I tried to speak and she understood me. When we came back, I started watching cartoons and TV shows in English, a habit that has not changed till today.

O.V., Year 2 part-time student

I was in Poland where I played football. Coach did not speak Latvian or Russian, so I had to communicate in English.

\section{P., male, Year 1 full-time student}

I started reading news on web, when I was 10 years old, learned such basketball terms as airball, pic'n'roll, clutch shooter...

K.M., male, Year 1 full-time student

I learned English watching sport channels like Eurosport. Also I learned English reading newspapers and some information in Internet.

E., male, Year 1 student

I improved my English by travelling abroad and speaking to people

A.B., female, Year 2 part-time student

Sport, as well as music, helps to learn English faster ... I have worked as sports journalist and reporter, this winter I had an excellent opportunity to comment World and European Orienteering Championship. The option was to comment all competition in English, thus I raised my language level to new heights: learned new words, expressions, skills, helping to make better sentence structure and to improvise.

A.R., male, Year 2 part-time student

I learned English playing computer games, and at school too. Then I went to UK to work in a warehouse, there I had two friends from Ghana, Africa, who always wanted to speak to me - in three months my English was ten times better.

M.S., male, Year 2 full-time student

I have helped to organize sport games, in which participated foreigners, who spoke English, thus I learned a lot of new terms and words connected with sport events.

P., 20, male. 
Content analysis of student scripts allowed identifying two key ways of the development of student foreign language skills:

1) sports related - participation in training, competitions, studies abroad; reading sports news, watching sport related programs (Eurosport, etc.),

2) not sports related - watching cartoons, TV shows; listening to music.

Content analysis also allowed identifying main agents of communication in:

1) sportive environment: coaches, referees, managers, peers,

2) non-sportive environment: at school, in student exchange programs.

\section{Quantitative analysis}

A questionnaire, consisting of 12 statements with responses in 4-point Likert scale, consisted of three blocks, corresponding to student language learning and use habits in past, present and future.

First question in each block was about the ways of learning English: "How did you learn English?". The answers ranged from "at school" and "going abroad with training group" to "listening to songs" and "watching cartoons".

Next question in each block was about the use of English. The answers ranged from communicating with other athletes and coaches to conversations with referees and managers.

The following question aimed to reveal the frequency of using English in past, present and future. The answers ranged from "very often" to "very rarely".

The last two questions aimed to find out whether trainings and conducting trainings helps (helped) or impedes (impeded) learning English. The answers were: helps (helped), impedes (impeded), neither helps (helped), nor impedes (impeded).

The students were asked to fill in the questionnaire during their first class of sport English.

\section{Results}

1. Foreign language use habits

The analysis of foreign language use in the past and at present reveal that most of the students used and still use foreign language either often or rarely (both indicators: $34.3 \%$ ), in the past foreign language was used very rarely used by considerable amount of respondents: $25.7 \%$, but at present: only by $14.3 \%$, very often foreign language in the past was used only by $5.7 \%$ of respondents, but now: already by $8.6 \%$. In future no one sport specialist is going to use foreign language very rarely, most are going to use it often (74.3\%), very often foreign language will use $11.4 \%$ of respondents. The change of the frequency of foreign language use in past and in future is shown in Figure 1 and Figure 2. 


\section{percentages}

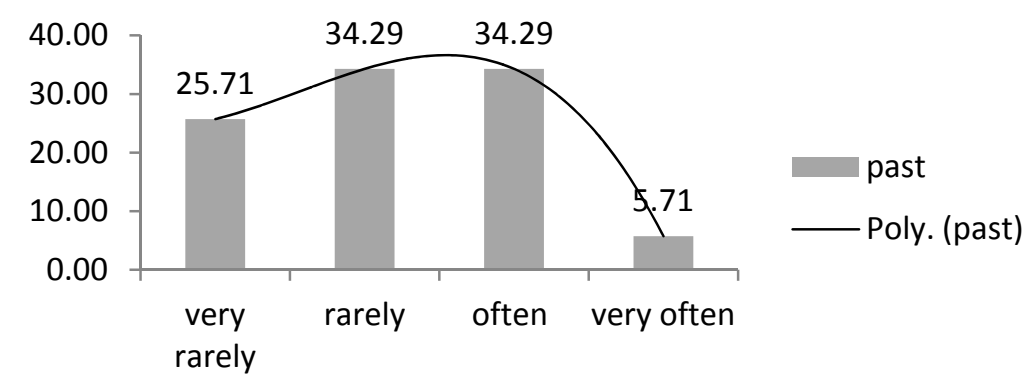

Figure 1. Frequency of foreign language use in past

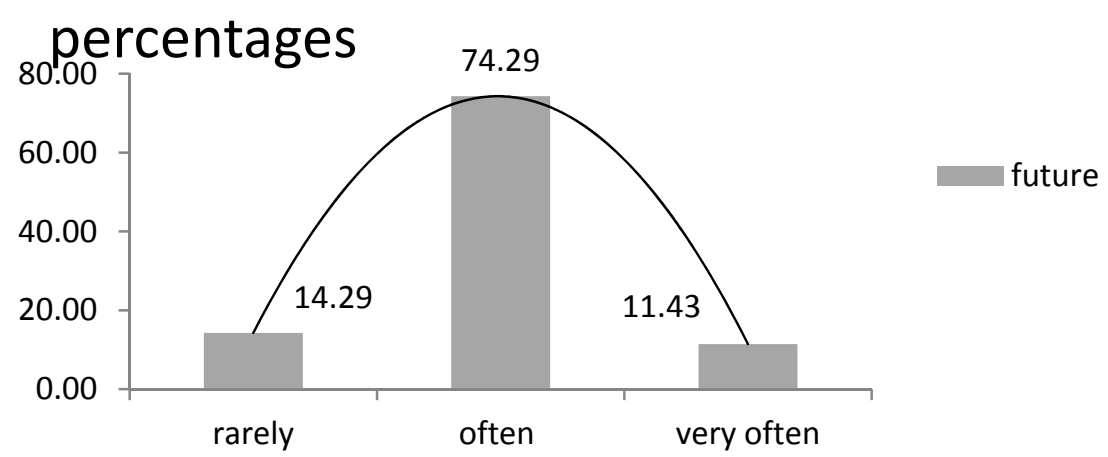

Figure 2. Planned frequency of foreign language use in future

Tendency curve shows that in past most young sportsmen used foreign language very rarely, rarely and often, whereas in future most sports specialist intend to use it often.

Respondents mostly spoke to other sportsmen (54.3\%) and coaches (14.3).

At present respondents mostly speak to other sportsmen $(54.3 \%)$, coaches $(22.9 \%)$, and referees $(28.6 \%)$.

In future sport specialists intend to speak to other sportsmen (77.1\%), coaches (74.3), and referees: 54.3, sport managers, sport agents, a.o. sport related people. 2. The development of foreign language skills

Most of respondents find it easy to speak foreign language: $45.7 \%$ speaking skills are satisfactory, 28.6\%: well developed.

All in all foreign language use skills are moderately developed: $60 \%$ of respondents find it neither difficult, nor easy to read, and also to write in foreign language. Only $17.1 \%$ consider that they are good at writing, and $22.9 \%$ : at reading.

In future sport specialists intend to learn English in post-graduate studies $(22.9 \%)$.

Surprisingly enough that $45.7 \%$ of respondents, having studied foreign language at school and in undergraduate studies, are still going to attend foreign language courses. 


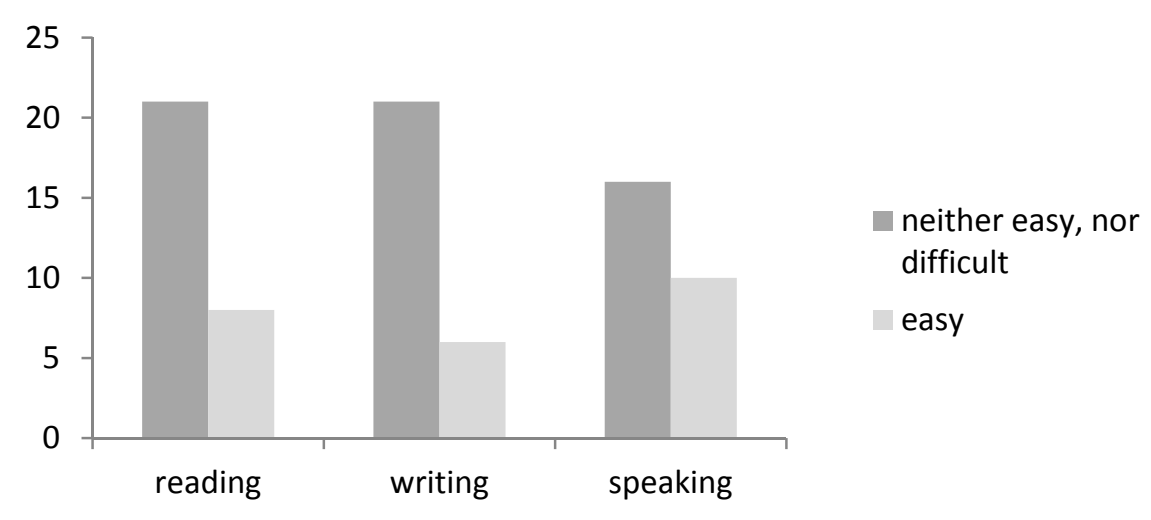

Figure 3. Communication in foreign language

Future sports specialist will read literature in foreign language (65.7\%), and write e-mails (40\%).

Respondents acknowledge that they will also learn foreign language in an informal way: travelling abroad with their training group (42.9\%), watching sports channels, including Euro sport (28.6\%), as well as watching movies and listening to songs.

\section{percentages}

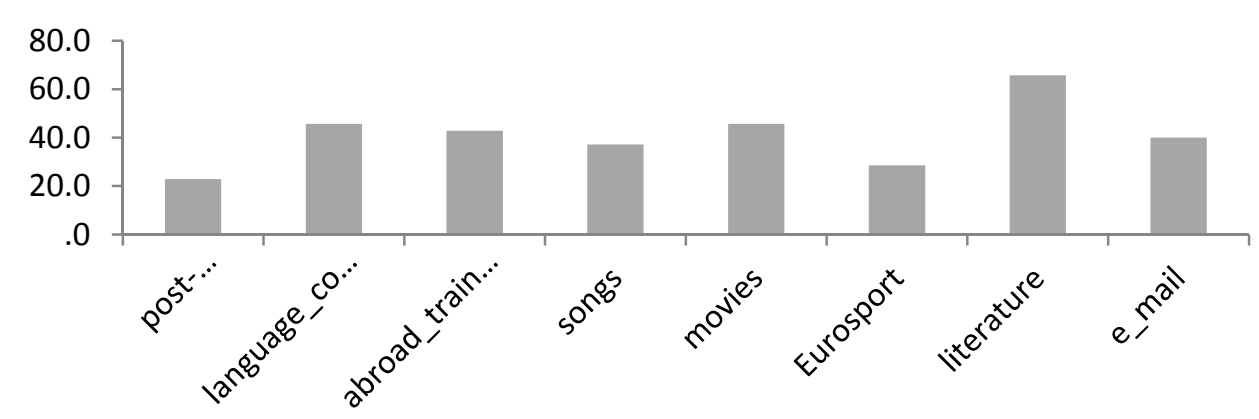

Figure 4. Ways of foreign language learning in future

3. Relationship between active engagement in sporting activities and the development of foreign language skills

Student answers show that in the past participation in sport activities helped (45.7\%) and neither helped, nor impeded the development of foreign language skills and competences (48.6\%), 2 students asserted that sporting activities impeded the development of foreign language skills.

At present the situation is similar: participation in sport activities helps (45.7\%) and neither helps, nor impedes the development of foreign language skills and competences (45.7\%), 3 students assert that sporting activities impede the development of foreign language skills. One respondent told that he was playing beach volleyball in Turkey, and his partner was Turkish too, so his English skills were decreasing because of no opportunity to use them. Conducting trainings 
also neither helps, nor impedes the development of foreign language skills and competences $(57.1 \%)$.

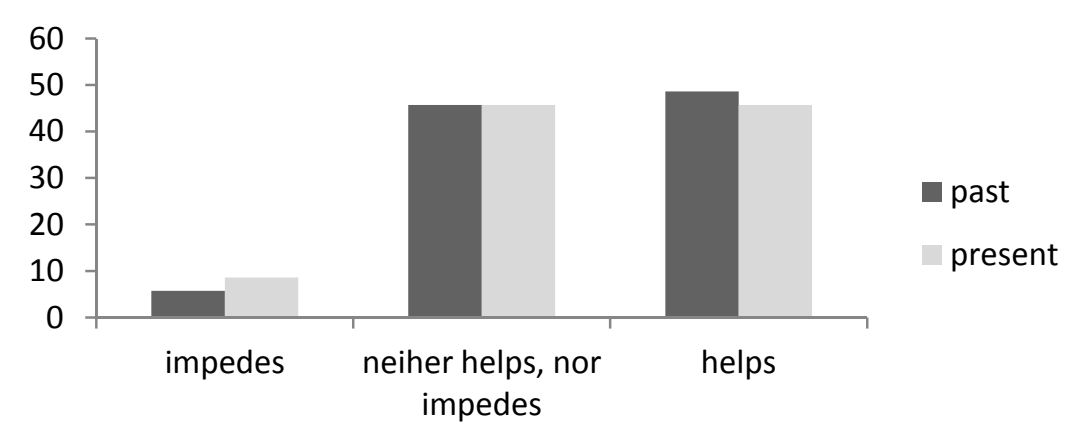

Figure 5. Relationship between engagement in sport and foreign language learning

Figure 5 shows that engagement in sport activities both in the past and in present in most cases helps in the development of foreign language and neither helps, nor impedes the development of foreign language. Thus straightforward conclusion that engagement in sporting activities always helps to develop foreign language use skills cannot be drawn.

\section{Conclusions}

The results show that sports persons learn foreign language in a lot of formal and informal ways. Active engagement in sporting activities besides formal foreign language learning at school can bring them into international environment, promote meeting young sportsmen from other countries, and the only way to communicate often turns out to be English. Also new technologies offer a lot of ways to watch sports channels and read sports news. Best young sportsmen often spent a lot of time abroad in training camps, communicating with peers and coaches in foreign language.

Sports persons use English more and more: at present more than in past, and in future more than at present. It is strange that considerable number of sports persons intends to study foreign language also at language courses. This finding means that about 10 years of studying foreign language at school and higher education institutions has not been sufficient for their needs.

Teaching staff of the concerned sport related higher education institution also consider that their English proficiency is not sufficiently high. Lecturers and professors have to communicate with Erasmus and foreign students, what is not always easy, especially for soviet school graduates, where was taught only knowledge of English, not skills of using English and competences, based on skills. Lecturers and professors also have to read their specialty related literature in English, and communicate with their colleagues in formal and non-formal environment. Considering the abovementioned, staff members participate in lifelong adult learning programs, and/or attend special courses organized in the HEI. 
Evidence does not prove always positive influence of sporting activities on learning foreign language. Therefore the causes for male sport student higher than usual foreign language skills, equaling with those of female sport students, should be sought also in other spheres, including psychological and physiological.

\section{References}

1. Brizendine, Louann, M.D. (2006), The Female Brain, Crown Publishing Group.

2. Cameron, D. (2007), "Unanswered questions and unquestioned assumptions in the study of language and gender: Female verbal superiority", Gender and Language, Vol. 1, pp. $15-25$,

3. Geske, A., Ozola, A. (2007), Skolēnu sasniegumi lasītprasmē Latvijā un pasaulē (Student achievement in reading literacy in Latvia and the world), Rịga, LU Akadēmiskais apgāds.

4. Johansone, I. (2003). Startautiskais lasītprasmes novērtēšanas pētījums 2000-2003 (International PIRLS investigation 2000-2003), Rīga, Mācību grāmata.

5. Omrčen, D., Bosnar, K. (2010). Gender Stereotyping Bias - Assessment of the Swimming and Underwater Diving Vocabulary Knowledge in English as a Foreign Language in Kinesiology, pp. 1-6. In S. Orthaber and P. Vičić (eds.) Proceedings CD of the international language conference "The importance of learning professional foreign languages for communication between cultures", Celje, Slovenia, University of Maribor, Faculty of Logistics.

6. Rudzinska, I. (2011). "Bridging the gender gap in student professional foreign language competence" In S. Orthaber and P. Vičić (eds.) Proceedings $C D$ of the international language conference "The importance of learning professional foreign languages for communication between cultures", Celje, Slovenia, University of Maribor, Faculty of Logistics.

7. Sonstroem, R.J., (1997). The physical self-esteem: A mediator of exercise and selfesteem, In K.R., Fox (Ed.), The physical self (pp. 3-26). Champaign, IL: Human Kinetics.

8. Wolf, E., Zwick, T. (2002). Reassessing the Impact of High Performance Workplaces, ZEW Discussion Paper No. 02-07, Mannheim, forthcoming in Schmalenbach Business Review (2008).

$\begin{array}{ll}\text { Dr.sc.admin., Assistant } & \text { Latvian Academy of Sport Education, Department of } \\ \text { Professor } & \text { Management and Communication Science, Latvia } \\ \text { Ieva Rudzinska } & \text { Brivibas gatve 333, Riga, LV - 1006, Latvia } \\ & \begin{array}{l}\text { Phone: +371-67543445, fax: +371-67543480 } \\ \text { e-mail: Ieva.Rudzinska@1spa.lv }\end{array} \\ \text { Dr.paed., Leading } & \text { Latvian Academy of Sport Education, Department of } \\ \text { Researcher } & \text { Management and Communication Science, Latvia } \\ \text { Monta Jakovleva } & \text { Brivibas gatve 333, Riga, LV - 1006, Latvia } \\ & \text { Phone: +371-67799532, fax: +371-67543480 } \\ & \text { e-mail: Monta.Jakovleva@1spa.lv }\end{array}$

